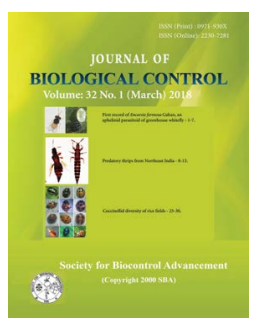

Research Article

\title{
Molecular mechanisms adopted by abiotic stress tolerant Pseudomonas fluorescens (NBAII-PFDWD) in response to in vitro osmotic stress
}

\author{
KARKERA ASHWITHA*, RAJAGOPAL RANGESHWARAN and GOPALSAMY SIVAKUMAR \\ ICAR, National Bureau of Agricultural Insect Resources, Hebbal, Bellary Road, Bangalore - 560024, Karnataka, India \\ *Corresponding authorE-mail: ashwi1986@gmail.com
}

\begin{abstract}
Water stress in one of the limiting factors which influences the plant growth. Microbes being as a partner are an integral part of the ecosystem which influences the plant growth under stress. In the present study, Pseudomonas fluorescens (NBAII- PFDWD) subjected to osmotic stress by altering osmotic potential (-10.28 MPa and $-26.82 \mathrm{MPa}$ ) using Polyethylene Glycol (PEG) 6000 in its growth media revealed expression of proteins which modulates its cell processes. MALDI TOF studies of selected spots from 2D gel analysis of P. fluorescens (NBAII- PFDWD) grown under different osmotic stresses revealed that the stress kindled genes which were involved in production of osmoprotectants, genes encoding DNA damage repair and increased the translational accuracy. The studies also showed that P. fluorescens possesses unique mechanisms for survival under osmotic stress. The studies indicate the diverse expression of proteins in P. fluorescens (NBAII- PFDWD) under different osmotic potentials which helped them to mitigate impact of osmotic stress. The present method unravelled the mechanisms adopted by P. fluorescens (NBAII- PFDWD) to thrive under osmotic stress. The bacterium is potential stress tolerant isolate which can be exploited as a plant growth promoting rhizobacteria for agricultural crops grown in stressed soils.
\end{abstract}

KEY WORDS: MALDI- TOF, osmotic potential, osmotic stress, Pseudomonas fluorescens, PEG 6000

(Article chronicle: Received: 02-12-2017; Revised: 26-02-2018; Accepted: 18-03-2018)

\section{INTRODUCTION}

Bacteria surviving in soil are continuously exposed to number of stresses viz., flooding, high and low temperatures, drought and chemicals. The scientific studies to understand the mechanisms followed by bacteria are interesting and bring forward the survival strategy ratified by them. Bacteria alter their gene expression patterns producing proteins which help them to cope these stresses (Boor, 2006). Stress induced alteration in metabolic pathways including translation is one of the multitude ways to survive under stressful conditions. Protein synthesis is a vital part in cell function as it maintains the fidelity of genetic information (Karas, 2015).

The lipid membrane of Gram negative bacteria maintains stability by balancing its solute content and the osmotic pressure of environment. Pseudomonas spp. managed the variation in homeostasis by accumulating compatible solutes by de novo synthesis, trehalose, glutamate, man- nitol, glucosylglycerol, ectoine, and hydroxyectoine; other osmotolerance mechanisms include accumualtion of $\mathrm{K}+$ ions, proline, gamma aminobutyrate, -aminobutyrate, alanine, the quaternary amines glycinebetaine, fully $\mathrm{N}$ methylated amino acid derivatives, sucrose, trehalose ( -D-glucopyrano-syl- -D-glucopyranoside) and glucosylglycerol (Kets et al., 1996; Freeman et al., 2010, 2013). Transcriptional regulation of certain genes like ProU, OmpF, OmpC also occur under osmotic changes (Csonka, 1989). Bacterial sigma factors support bacterial growth and regulate physiological development under stress (Boor, 2006). In addition, membrane transporter and porins facilitate translational stress response under osmotic stress (Wood, 2015). Osmotic potential is used to measure the osmotic property of the bacterial environment.

Pseudomonas spp. is ubiquitous and flourishes in diverse habitats. They produce wide variety of stress response system to adapt under environmental changes (Udaonda et al., 2012). Pseudomonas spp. confers drought resistance by 
accumulation of exopolysaccharides and osmolytes which make it notable to use as efficient PGPR in soils (Sandhya et al., 2009).

Pseudomonas fluorescens is widely used as a biological control agent but the mechanism it opts to survive under low moisture conditions is less understood. In the present investigation, our objective was to understand mechanisms executed by Pseudomonas fluorescens (NBAII- PFDWD) to survive under osmotic imbalance. Pseudomonas fluorescens (NBAII- PFDWD) isolated from rhizosphere soil is tolerant to high temperature, salinity, $\mathrm{pH}$ and osmotic stress (Ashwitha et al., 2013). In vitro studies were designed to grow the culture in PEG 6000 mediated osmotic stress in media. PEG, is a polymeric co solvent results in osmotic shifts which lead to change in membrane structure by regulating efflux or influx of solvents to maintain balance (Wood, 1999). Pseudomonas fluorescens (NBAII-PFDWD,
GenBank HM439956) was selected as an abiotic stress tolerant organism during screening of several isolates. It was found tolerant to $45^{\circ} \mathrm{C}$, salinity $(1.5 \mathrm{M} \mathrm{NaCl}), \mathrm{pH} 9.0$ and also moisture stress. The protein profiling of the $P$. fluorescens (NBAII- PFDWD) grown under stress condition was done using 2D gel electrophoresis and major spots corresponding to stress genes were identified using MALDI -TOF analysis.

\section{MATERIAL AND METHODS}

Osmotic stress mediated growth of Pseudomonas fluorescens (NBAII- PFDWD)

Pseudomonas fluorescens (NBAII- PFDWD GenBank HM439956) was used in the study for investigating the growth under osmotic stress. $50 \mu$ of mid-log-phase culture (12 h) of P. fluorescens (NBAII- PFDWD) was inoculated to $250 \mathrm{ml}$ Erlenmeyer flask containing $100 \mathrm{ml}$ of nutrient broth $\left(\mathrm{g} / \mathrm{L}^{-1}\right)$ Peptone, 5g; Beef extract, 3g; $\left.\mathrm{NaCl}, 5 \mathrm{~g}\right)$

Table 1. List of selected MALDI- TOF identified proteins expressed by Pseudomonas fluorescens (NBAII-PFD WD) under different osmotic potentials

\begin{tabular}{|c|c|c|c|c|c|}
\hline \multirow{2}{*}{$\begin{array}{l}\text { Stress condi- } \\
\text { tion }\end{array}$} & \multirow{2}{*}{$\begin{array}{l}\text { Spot } \\
\text { no. }\end{array}$} & \multirow[t]{2}{*}{ Protein name (Swiss Prot Database) } & \multicolumn{3}{|c|}{ Log Normalized Values } \\
\hline & & & $0 \mathrm{MPa}$ & $-10.28 \mathrm{MPa}$ & $-26.82 \mathrm{MPa}$ \\
\hline \multirow{7}{*}{$\begin{array}{l}\text { Normal } \\
\text { growth condi- } \\
\text { tion }\end{array}$} & 241 & 2-isopropylmalate synthase OS & 5.34 & 5.11 & 4.82 \\
\hline & 240 & $\begin{array}{l}\text { Probable dual-specificity RNA methyltransferase } \\
\text { RlmN OS }\end{array}$ & 4.95 & 4.64 & 4.46 \\
\hline & 477 & 30s ribosomal protein S8 OS & 5.54 & 5.12 & 5.11 \\
\hline & 482 & Exodeoxyribonuclease 7 small subunit OS & 5.62 & 5.19 & 5.05 \\
\hline & 336 & Bifunctional pantoate ligase/cytidylate kinase OS & 4.18 & 3.94 & 3.78 \\
\hline & 391 & Cellular nucleic acid-binding protein homolog OS & 4.84 & 4.34 & 4.36 \\
\hline & 392 & Threonine--tRNA ligase OS & 4.72 & 4.48 & 4.40 \\
\hline \multirow{8}{*}{$\begin{array}{l}30 \% \text { PEG } \\
\text { stress } \\
(-10.28 \mathrm{OP})\end{array}$} & 496 & Dihydrorotate dehydrogenase (quinone) OS & 5.43 & 5.54 & 5.56 \\
\hline & 90 & Ribosome-recycling factor OS & 2.95 & 2.61 & 3.18 \\
\hline & 147 & L-ectoine synthase & 4.01 & 4.44 & 4.00 \\
\hline & 156 & Arginine deiminase OS & 5.49 & 5.50 & 5.48 \\
\hline & 222 & $\mathrm{~N}$-acetylmannosamine kinase OS & 4.88 & 4.91 & 4.96 \\
\hline & 347 & DNA replication and repair protein RecF OS & 4.56 & 4.53 & 4.46 \\
\hline & 354 & Phosphate acyltransferase OS & 5.08 & 4.99 & 4.98 \\
\hline & 367 & DNA repair protein RecO OS & 5.14 & 5.01 & 4.95 \\
\hline \multirow{15}{*}{$\begin{array}{l}50 \% \text { PEG } \\
\text { stress } \\
(-26.82 \text { OP })\end{array}$} & 429 & Transcription elongation factor GreA OS & 4.36 & 4.72 & 5.01 \\
\hline & 426 & Elongation factor Ts OS & 5.16 & 5.17 & 5.23 \\
\hline & 486 & Crossover junction endodeoxyribonuclease RuvC OS & 4.87 & 4.92 & 4.93 \\
\hline & 184 & Pantothenate synthetase OS & 4.08 & 4.31 & 4.43 \\
\hline & 218 & $60 \mathrm{kDa}$ chaperonin OS & 4.20 & 4.40 & 4.43 \\
\hline & 206 & DNA mismatch repair protein MutL OS & 4.97 & 4.73 & 4.98 \\
\hline & 248 & V-type proton ATPase subunit E OS & 4.50 & 4.13 & 4.32 \\
\hline & 263 & Gamma-glutamyl phosphate reductase OS & 4.77 & 4.81 & 4.89 \\
\hline & 439 & Ribonuclease HII OS & 4.87 & 4.85 & 4.83 \\
\hline & 326 & Transcriptional repressor NrdR OS & 4.75 & 4.84 & 4.94 \\
\hline & 355 & Leu operon leader peptide OS & 4.28 & 4.44 & 4.53 \\
\hline & 373 & Fructose-1,6-bisphosphatase class 2 OS & 3.96 & 4.23 & 4.37 \\
\hline & 396 & $\begin{array}{l}\begin{array}{l}\text { Putative ATP-dependent Clp protease proteolytic } \\
\text { subunit-like OS }\end{array} \\
\end{array}$ & 4.60 & 4.47 & 4.56 \\
\hline & 390 & Bifunctional protein GlmU OS & 4.08 & 4.34 & 4.44 \\
\hline & 368 & NAD(P)H-quinone oxidoreductase subunit O OS & 4.51 & 4.67 & 4.68 \\
\hline
\end{tabular}



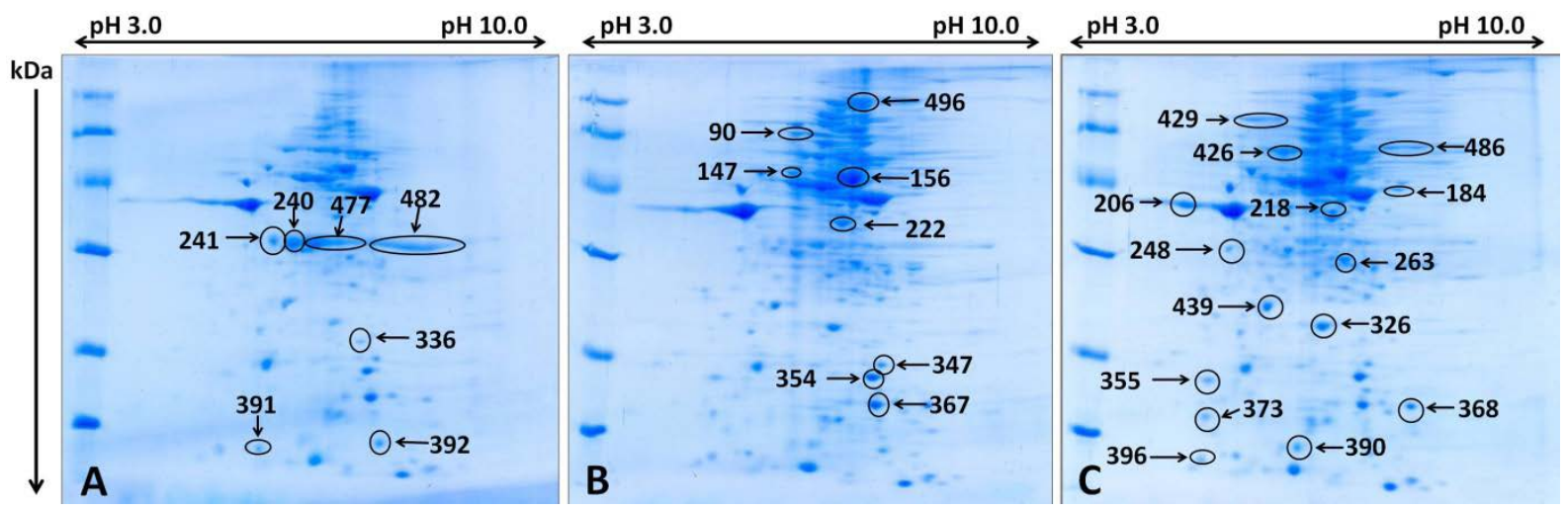

Fig. 1. Ezee blue stained SDS PAGE gel after IEF showing different protein spots expressed by Pseudomonas fluorescens (NBAII-PFDWD) at different osmotic potentials, A; 0 MPa, B; -10.26 MPa and C; -26.82 MPa. The spots selected for MALDI-TOF are circled in black.

amended with PEG 6000 to attain different osmotic potentials () of $0 \mathrm{MPa},-10.28 \mathrm{MPa}$ and $-26.82 \mathrm{MPa}$ concentrations. The $\mathrm{pH}$ of the media was adjusted to $7.2 \pm 2$. The cultures were incubated at $28 \pm 2{ }^{\circ} \mathrm{C}$ under constant shaking.

\section{Extraction of bacterial proteins}

The bacterial cells were collected by centrifugation $(10,000 \mathrm{~g}$ for $10 \mathrm{~min})$ and washed three times with isotonic solution. The proteins were precipitated according to method described by Paul et al. (2006). The protein extracts were frozen until further use.

\section{D Gel analysis for stress-related proteins}

The first dimension was carried out at Genei TM Merck Biosciences, Bangalore, India as per standardized protocol. Gel mixture was prepared containing $10.8 \mathrm{M}$ urea, $30 \%$ acrylamide, $20 \mu \mathrm{l}$ of $100 \%$ Triton-X, $130 \mu \mathrm{l}$ ampholyte $\mathrm{pH}(3-10), 3 \mu \mathrm{T}$ TEMED and APS (10\%). The 1D was carried out in EttanIPGphor3 (GE Health care). The gel mixture was poured in tube by using (18-gauge needle) syringe up to $15 \mathrm{~cm}$ without any air bubble (remaining $1 \mathrm{~cm}$ for sample loading space). Once the gel was set the casted gel tube was fixed to the tank with rubber grommet very tightly (sample loading space of tube facing toward the top reservoir). The reservoir top was filled with $1 \mathrm{X}$ cathode buffer $(400 \mathrm{mM} \mathrm{NaOH})$ and bottom reservoir with $1 \mathrm{X}$ anode buffer $\left(100 \mathrm{mM} \mathrm{H}_{3} \mathrm{PO}_{4}\right)$. The gel was pre-focused by adding $1-3 \mu \mathrm{l}$ of $2 \mathrm{D}$ SLB [9.8 M urea, $2 \% \mathrm{NP}-40$ (10\% in distilled water), $2 \%$ carrier ampholytes $8 / 10,25 \mathrm{mM}$ DTT] into sample loading space and power cords were connected to the power supply. Electrophoretic conditions of the rod gels during the IEF (pre-run) were $200 \mathrm{~V}$ for $15 \mathrm{~min}, 300$ $\mathrm{V}$ for $30 \mathrm{~min}$, and $400 \mathrm{~V}$ for $1 \mathrm{~h}$. After IEF (pre-run), 350 $\mu \mathrm{g}$ of sample was loaded and gel was run at $400 \mathrm{~V}$ for $16 \mathrm{~h}$. After $16 \mathrm{~h}$, the gels were transferred to a small tray contain- ing 2D equilibration buffer [6 $\mathrm{M}$ urea, $75 \mathrm{mM}$ Tris- $\mathrm{HCl}(\mathrm{pH}$ 8.8 ), $29.3 \%$ glycerol, $2 \%$ SDS, $0.002 \%$ bromophenol blue] and left for $30 \mathrm{~min}$.

The second dimension was carried out on $12.5 \%$ SDS PAGE. The equilibrated gel was placed on $1 \%$ agarose added on the top of the polymerized SDS-gel. Electrophoresis was carried out at $150 \mathrm{~V}$ in Genei ${ }^{\mathrm{TM}}$ Vertical Maxi Gel system. Protein spots were visualized using Ezee blue gel stainer $\left(\mathrm{Genei}^{\mathrm{TM}}\right)$ and the well-resolved spots were numbered. The Mr of individual protein spots was determined by comparison with molecular weight markers. Spot detection was carried out using the software, Progenesis (Nonlinear Dynamics available at www.nonlinear.com). The two-dimensional gels of $P$. fluorescens (NBAII- PFDWD) grown in all three osmotic conditions were compared using this software.

\section{Protein identification}

Selected proteins were subjected to in-gel proteolytic digestion by excising 1-mm-thick gel and washing for 30 $\mathrm{min}$ at room temperature under vigorous shaking with $400 \mu \mathrm{l}$ of $10 \mathrm{mM}$ ammonium bicarbonate solution containing 50\% $(\mathrm{v} / \mathrm{v})$ acetonitrile. The gel pieces were dried for $15 \mathrm{~min}$ in a vacuum concentrator. The rehydrated gel pieces were incubated in $150 \mu$ l reduction solution (10 mM DTT, $100 \mathrm{mM}$ ammonium bicarbonate) for $30 \mathrm{~min}$ at $56^{\circ} \mathrm{C}$. The reduction solution was then discarded and $100 \mu$ alkylation solution (50 $\mathrm{mM}$ iodoacetamide, $100 \mathrm{mM}$ ammonium bicarbonate) was added for $30 \mathrm{~min}$ in dark at room temperature. The gel pieces were digested in $5 \mu \mathrm{l}$ trypsin solution (sequencing grade modified trypsin, Promega, Madison and $10 \mathrm{ng} / \mu \mathrm{l}$ in $5 \mathrm{mM}$ ammonium bicarbonate $/ 5 \%$ acetonitrile). The samples were incubated for $5 \mathrm{~h}$ at $37^{\circ} \mathrm{C}$. The reaction was stopped by adding $1 \mu \mathrm{l}$ of $1 \%$ trifluoroacetic acid. For better extraction of peptides, the samples were stored overnight at $5{ }^{\circ} \mathrm{C}$. 


\section{MALDI-TOF MS Identification of Protein}

The analysis was carried out in MALDI-TOF mass spectrometer (Bruker-Daltonics, Germany) at Merck Biosciences, Bangalore, India. The $1 \mu \mathrm{l}$ of concentrated peptides from the supernatant was mixed with $2 \mu \mathrm{l}$ of matrix solution [5 mg a-cyano-4-hydroxycinnamic acid in $40 \%(\mathrm{v} / \mathrm{v})$ acetone, $50 \%(\mathrm{v} / \mathrm{v})$ acetonitrile, $9.9 \%(\mathrm{v} / \mathrm{v})$ water, and 0.1 $\%(w / v)$ TFA in water]. From this mix, $1 \mu l$ was deposited onto the MALDI target. Tryptic peptides were analyzed in positive mode. Background ions from trypsin autolysis and contamination by keratins were removed from mass lists. The proteins were analysed using MASCOT search engine in latest version of the NCBInr database with following relevant search parameters viz., monoisotopic mass accuracy, peptide mass tolerance $(0.1 \mathrm{Da})$, peptide charge state, allowed variable modifications, oxidation of methionine and fixed modification, carbamidomethylation of cysteine. Fragmentation of selected peptides was measured using the PSD mode. The percentage similarity of amino acids, $\mathrm{Mr}$ and $\mathrm{pI}$ were taken into consideration for identification of the proteins from bacteria of related species/genera.

\section{RESULTS AND DISCUSSION}

Capability of $P$. fluorescens (NBAII- PFDWD) to survive osmotic stress is well addressed in the protein profiling technique. The stress response of $P$. fluorescens (NBAIIPFDWD) subjected to osmotic stress at different osmotic potential using PEG 6000 revealed wide array of proteins produced by translational modification. Overall more than 300 proteins were expressed in all the three growth conditions. Thirty distinctive spots were selected based on Prolinear software from protein profile gels of all the three growth conditions subjected viz., $0 \mathrm{MPa},-10.28 \mathrm{MPa}$ and $-26.82 \mathrm{MPa}$ (Fig. 1) and identified using MALDI-TOF MS. The proteins were abundant under osmotic stress conditions, $-10.28 \mathrm{MPa}$ and $-26.82 \mathrm{MPa}$ when compared to the normal conditions. Seven spots were detected from protein gel of $0 \mathrm{MPa}$ which were down regulated under osmotic stress (Fig. 1). Eight proteins and 15 proteins which were up regulated under $-10.28 \mathrm{MPa}$ and $-26.82 \mathrm{MPa}$ were selected for identification respectively. The fold increase of all these proteins are tabulated (Table 1). Comparison of proteins revealed that the expression levels of bifunctional pantoate ligase/cytidylate kinase OS decreased under $-10.28 \mathrm{MPa}$ and -26.82 MPa induced osmotic stress. L-ectoine synthase expression was higher under -10.28 MPa induced osmotic stress, however, its expression was almost on par under normal conditions and -26.82 MPa induced stress.

The spot details obtained from Progenesis software clearly distinguishes spots corresponding to transcription elongation factor GreA OS and fructose-1,6-bisphosphatase class 2 OS were up regulated under both cases of osmotic stress. Their expression under normal condition was barely visible in gel. In both osmotic stress conditions, exodeoxyribonuclease 7 small subunit OS was down regulated. Comparison among all the three gels showed that, arginine deaminase OS, DNA replication and repair protein RecF OS, phosphate acyltransferase OS and DNA repair protein RecO OS showed no significant difference in their expression under normal and osmotic stress conditions (Fig. 2, 3 ). It was noticed that the 11 proteins selected from both osmotic stress conditions were on par except four identified as transcription elongation factor GreA OS, $60 \mathrm{kDa}$ chaperonin OS, DNA mismatch repair protein MutL OS and Gamma-glutamyl phosphate reductase OS which showed slight increase under -26.82 MPa induced osmotic stress.

In order to survive under moisture stress, Pseudomonas fluorescens (NBAII-PFDWD) produced an array of proteins which helped them mitigate the stress conditions. Most of the proteins shown to over express under moisture condition by P. fluorescens (NBAII- PFDWD) are not reported so far. The current study is novel and has provided an initial platform to explore microbial interaction under stressed ecosystem. Literature studies reveal that all these genes are expressed as stress response in different microorganisms. 2-isopropylamalate synthase was expressed in osmotic stress subjected in Campylobacter jejuni and it belongs to transferases involved in L-leucine and pyruvate metabolism (Cameron et al., 2012). RlmN is associated with catalysis of m2A sythesis with both rRNA nd tRNA. The translation accuracy decreased with inactivation of R $1 \mathrm{mN}$ in E.coli (Benitez- Paez and Villarrayo, 2012). This function reduces the chances of misreading of translational reading frame and further balance bacterial phenotype which could impair under stress conditions. Many genes are expressed for bacterial growth under a stable environment however, its expression varies when the bacteria challenges a distressed milieu. Ribosome profiling provides an insight to its role in expression of bacterial proteins under environmental fluctuations (Starosta et al., 2014). Expression of 30s ribosomal proteins were found to be down regulated in carnocyclin treated Listeria monocytogenes (Liu et al., 2014). DNA repair mechanisms play a pivotal role in altering stressed genes for a normal functioning of a cell. Exodeoxyribonuclease 7 small subunit plays important role in DNA repair by avoiding mutation occurring under environment instability (Lau et al., 2011; Lovett, 2011). DNA binding protein modulate biochemical functions, DNA binding and ferroxidase activity to protect cells from damage due to various stresses when in exponential growth and majorly when they enter stationary phase (Karas et al., 2015). No 
functional activity was reported for bifunctional pantoate ligase/cytidylate kinase OS under stress conditions. Hence precise regulation of these proteins is important under adverse conditions.
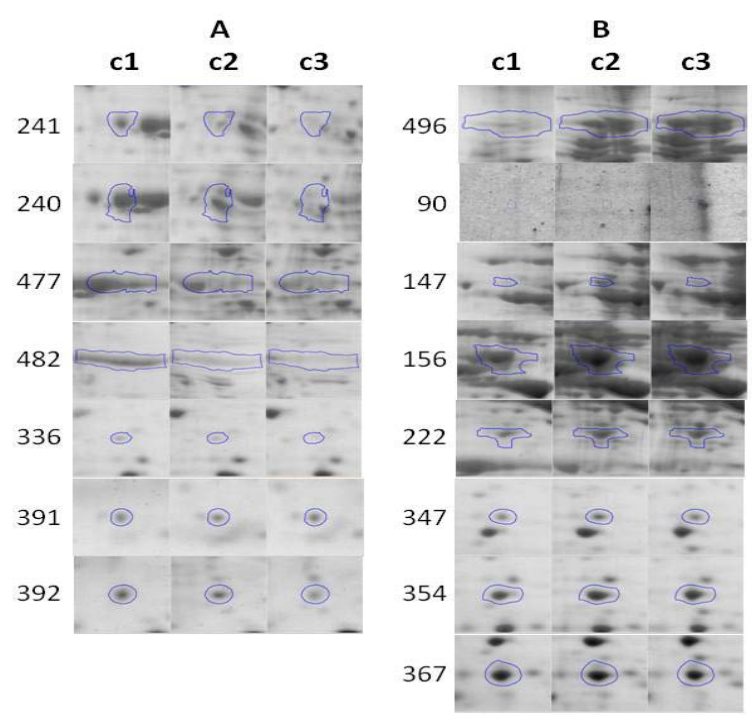

Fig. 2. A, Spots which are expressed under normal growth conditions (c1) analysed using Progenesis Linear Dynamics Software. Spots 241-392 are shown to be down regulated under conditions c2 (-10.28MPa) and c3 (-26.82 $\mathrm{MPa})$. B, differentially expressed genes under $\mathrm{c} 2$.

Stress involved proteins expression levels switch either by down regulating or up regulating. Eight spots were selected from gel profile of -10.28 MPa induced osmotic stress and fifteen from -26.82 MPa induced osmotic stress, all of which were differentially regulated under stress (Fig. 2,3). Dihydrorotate dehydrogenase (quinone) OS and arginine deiminase OS were expressed in higher folds under stress and dihydroorotate dehydrogenase (quinone) is involved in pyrimidine biosynthesis however, no function in stress response was observed (Jensen and Larsen, 2003; Kawasaki et al., 2009). Arginine deaminase stimulates the growth of Pseudomonas spp. and reverses the adverse effects in acidic environment by serving as energy source (Marquis et al., 1987). Ammonia derived from arginine deaminase breakdown reduced the effect of $\mathrm{pH}$ stress in Staphylococcus epidermidis (Lindgren et al., 2014). Ribosome-recycling factor OS, L-ectoine synthase, $\mathrm{N}$-acetylmannosamine kinase OS and phosphate acyltransferase OS were over expressed under this stress. Ribosome recycling is closely associated with protein synthesis which is required for bacterial growth. In $E$. coli it was shown that this gene is involve in dissociation of ribosome from mRNA after translation and in turn facilitates next cycle of protein synthesis (Borovinskaya et al., 2007; Li et al., 2012). Increase or decrease in cytoplasmic solutes is primary response to osmotic swing on bacteria. Ectoines belong to an array of compatible solutes produced majorly by halophilic bacteria and are in- volved in protein stabilization to prevent cell damage under osmotic or temperature stresses (Louis and Galinski, 1997; Kuhlmann et al., 2011). In addition ectoines serve as carbon and nitrogen source or as intracellular reserves (Pastor et al., 2010). Enzymes catalyse metabolic reaction in cell biosynthesis, N-acetylmannosamine kinases catalyse cell biosynthesis and cellular response to DNA damages stimulus. No reports are found with respect to expression of these stress proteins in P. fluorescens (NBAII-PFDWD). Acyltransferase utilizes fatty acid to form membrane phospholipids and further helps in membrane expansion. They regulate membrane biogenesis and cell growth. Notable function under stress is not known (Zhang and Rock, 2008). DNA replication is realm of bacterial survival. Osmotic stress induces perturbations in replication cycle. RecF influence the repair mechanism in responsible damage and replication fork stress in $E$. coli and B. subtilis (Lenhart et al., 2014; Villarrayo et al., 1998). Bacteria regulate membrane biogenesis of coordinate cell growth by synthesis of fatty acid. $\mathrm{RecO}$ are recombinant mediator protein involved in restarting of stalled replication in ssDNA gaps repair and in repairing dsDNA breaks. It is assisted in rapid repair of chromosome breaks in Deinococcus radiodurans under radiation and desiccation stress (Lusetti and Cox, 2002; Ryzhikov et al., 2011). Surprisingly, in the present study DNA replication and repair protein RecF OS and DNA repair protein $\mathrm{RecO}$ OS were found to be repressed under osmotic stress.

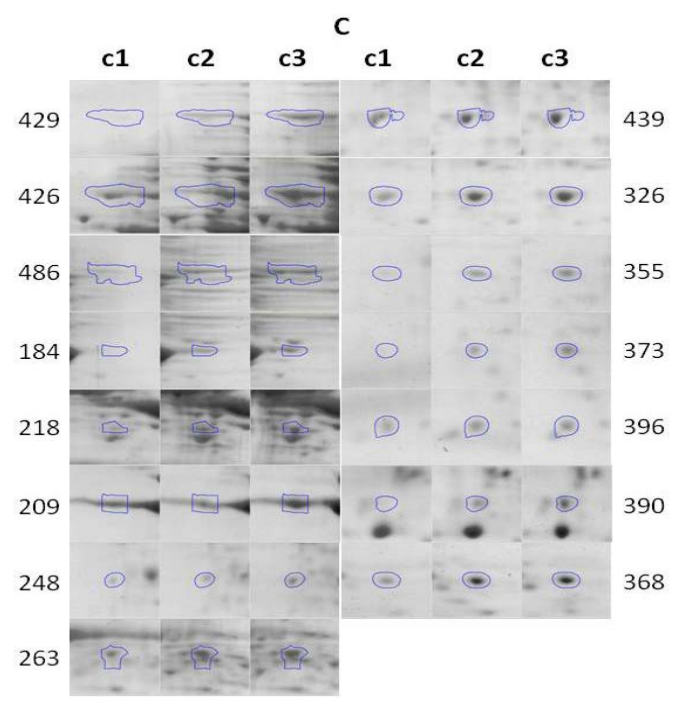

Fig. 3. Differentially expressed genes as analysed using Progenesis Linear software under c3 (-26.82 MPa).

A slight variation in osmotic potential of media prompted expression of proteins to express at higher folds. Nine proteins were up regulated when only $50 \%$ water availability was provided in media. GreA cleaves complexes formed at site of transcriptional arrest and resumes the transcriptional process additionally and they are up regualted in environmen- 
tal perturbations (Kusuya et al., 2011; Li et al., 2012). The genes which were up regulated were transcription elongation factor GreA OS, elongation factor Ts OS, crossover junction endodeoxyribonuclease RuvC OS, crossover junction endodeoxyribonuclease RuvC OS, pantothenate synthetase OS, $60 \mathrm{kDa}$ chaperonin OS, Gamma-glutamyl phosphate reductase OS, transcriptional repressor NrdR OS, Leu operon leader peptide OS, fructose-1,6-bisphosphatase class 2 OS, bifunctional protein GlmU OS and NAD(P)H-quinone oxidoreductase subunit O OS. RuV is involved in repair of DNA facing damage due to mutations. They encode endonucleases activities which resolve Holliday structure during recombination (Takahagi et al., 1991). No significant function was reported in stress mechanism however its major function lies in protein biosynthesis. $60 \mathrm{KDa}$ chaperonin or commonly referred E. coli GroeL is generally exhibited under temperature stress and is involved in unfolding the misfolded protein to its natural state (Maguire et al., 2002; Mande and Kumar, 2013). Gamma glutamyl phosphate reductase catalyses metabolic reaction of a major osmoprotectant proline encoded by ProA. Artificial bifunctional enzyme gamma-GK/gamma GPR expression in E.coli increased production of proline and osmotolerance of host (Chen et al., 2006; Liang et al. 2013). It is also associated with production of small amount of glutathione which is linked to proline biosynthesis under oxidative stress (Perez-Arellano et al., 2010). NrdR controls the transcription of genes by binding to promoter region. This regulatory protein controls expression of ribonucleoside reductases which are prescursors of DNA synthesis and repair during vegetative growth. These are important for aerobic growth of E. coli (Torrents et al., 2007). Fructose 1, 6-biphosphate class 2 OS play central function in glycolysis. Macomber et al. (2011) reported that the cellular over expression of fructose 1,6-biphosphate in E.coli reduced inhibitory effects of nickel. GlmU is a precursor for bacterial cell wall synthesis components like lipopolysaccharides and peptidoglycan. Inhibition of GlmU adversly affects cell viability (Larsen et al., 2012). Hence, this has been utilized as target for antibiotic drug discovery (Mochalkin et al., 2007). EF-Ts serves as the guanine nucleotide exchange factor for EF-Tu which is associated in response to nutrient deprivation and protect from stress (Caldas et al., 1998). NADPH- quinone oxidoreductase subunit is induced to protect cell from oxidative stress along with many other detoxifying enzymes (Atia et al., 2014). In E. coli they adapt and overcome a strong imbalance in NADPH redox state (Auriol et al., 2011). Down regulation of three proteins (V-type proton ATPase, Ribosome nuclease II, and Putative ATP-dependent Clp protease proteolytic subunit-like OS) at -26.82 MPa osmotic potential was observed in our study. V-type proton ATPase subunit is a membrane subunit whose major role is not much elucidated. Their function ranges from protein sorting to membrane trafficking. They drive the active transport systems in mem- brane. These V-type ATPases restrict the influx of external solutes so as to reduce risk of membrane integrity loss (Beyenback and Wiezoerek, 2006; Cohen, 2014). Ribosome nuclease II functions as exoribonucleolytic which is important for cell response to stress conditions. In E. coli activity of ribonuclease II was reduced under conditions of slow growth (Song et al., 2016). Similar case was observed in P. fluorescens (NBAII- PFDWD). RNA polymerases transcribe few genes to up regulate when bacteria reach its stationary phase and when its regular process shut downs (Lau et al., 2011). Clp mediates proteolysis of misfolded proteins subsequent to translation (Schelin et al., 2002). They exhibit adaptive response in $B$. subtilis against stationary phase phenomena like sporulation (Msadek et al., 1998). DNA repair was active through other set of genes like MutL. MutL belonging to mismatch repair system suppress chromosomal aberration by correcting mismatch bases during replication error occurring under various stress conditions (Harris et al., 1997) and helps in maintaining genetic stability (Oliver et al., 2002). Unlike other methyl directed mismatch proteins, MutL was functional even in stationary phase of E. Coli (Feng et al., 1996). In studies using $P$. syringae it was shown that osmotolerance was influenced by synthesis of $\mathrm{N}$-acetylglutaminylglutamine amide (NAGGN) that causes reduction of cellular glutamine indicating lower glutamine synthetase activity thereby causing glutamate accumulation (Freeman et al., 2013). In our studies up regulation of Gamma-glutamyl phosphate reductase OS was seen and this protein is involved in synthesizes of L-glutamate 5-semialdehyde from L-glutamate. Literature on stress response proteins expressed by a PGPR like $P$. fluorescens (NBAII-PFDWD) is very limited. The study has shown that $P$. fluorescens expressed a wide array of stress response genes which ameliorate its survival in environmental perturbations. The stress response genes identified are complex and P. fluorescens does possess unique pathways to survive under osmotic stress. The culture is being promoted as a useful biological control agent in stressed soils. Application of stress tolerant strains of microorganisms could be considered as a feasible choice in stress prone areas (Meena et al., 2017).

\section{ACKNOWLEDGMENT}

The authors are grateful to The World Bank and Indian Council for Agricultural Research (ICAR) for funding the Research under the National Agricultural Innovation Project (NAIP).

\section{REFERENCES}

Ashwitha K, Rangeshwaran R, Vajid NV, Sivakumar G, Jalali SK, Rajalakshmi K and Manjunath H. 2013. Characterization of abiotic stress tolerant Pseudomonas spp. occurring in Indian soils. J Biol Control. 27: 319328. 
Molecular mechanisms adopted by abiotic stress tolerant Pseudomonas fluorescens (NBAII-PFDWD) in response to in vitro osmotic stress

Atia A, Alrawaiq N, Abdullah A. 2014. A review of NAD(P) H:Quinone oxidoreductase 1 (NQO1); A multifunctional antioxidant enzyme. J Appl Pharma Sci. 4: 118-122.

Auriol A, Bestel-Corre G, Claude J, Soucaille P, Meynial-Salles I. 2011. Stress-induced evolution of Escherichia coli points to original concepts in respiratory cofactor selectivity. PNAS 108: 1278-1283. https://doi.org/10.1073/ pnas.1010431108 PMid:21205901 PMCid:PMC3029715

Benitez-Paez A, Villarayo M and Armengod. 2012. The Escherichia coli RlmN methyltransferase is a dualspecificity enzyme that modifies both rRNA and tRNA and controls translational accuracy. RNA 18: 1783-1795. https://doi.org/10.1261/rna.033266.112 PMid:22891362 PMCid:PMC3446703

Beyenback KW, Wiezoerck H. 2006. The V-type H + ATPase: molecular structure and function, physiological roles and regulation. J Exp Biol. 209: 577-589. https://doi. org/10.1242/jeb.02014 PMid:16449553

Boor KJ. 2006. Bacterial stress responses: What doesn't kill them can make them stronger. PLoS Biol. 4: 0018-0023.

Borovinskaya MA, Pai RD, Zhang W, Schuwirth BS, Holton JM, Hirokawa G, Kaji H, Kaji A. and Cate JHD. 2007. Structural basis for aminoglycoside inhibition of bacterial ribosome recycling. Nat Struct Mol Biol. 14: 727-732. https://doi.org/10.1038/nsmb1271\%20 PMid:17660832

Caldas TD, Yaagoubi AE, Richarme G. 1998. Chaperone properties of bacterial elongation factor EF-Tu. J Biol Chem. 273: 11478-11482. https://doi.org/10.1074/ jbc.273.19.11478. PMid:9565560

Cameron A, Fridrich E, Huynh S, Parker CT and Gaynor EC. 2012. Hyperosmotic stress response of Campylobacter jejuni. J Bacteriol. 194: 6116-6130. https://doi.org/10.1128/JB.01409-12 PMid:22961853 PMCid:PMC3486418

Chen M, Cao J, Zheng C, Liu Q. 2006. Directed evolution of an artificial bifunctional enzyme, c-glutamyl kinase/cglutamyl phosphate reductase, for improved osmotic tolerance of Escherichia coli transformants. FEMS Microbiol Lett. 263: 41-47. https://doi.org/10.1111/ j.15746968.2006.00397.x PMid:16958849

Cohen BE. 2014. Functional linkage between genes that regulate osmotic stress responses and multidrug resistance transporters: Challenges and opportunities for antibiotic discovery. Antimicrob Agents Chemother. 58: 640-646. https://doi.org/10.1128/AAC.02095-13 PMid:24295980 PMCid:PMC3910827
Csonka LN. 1989. Physiological and genetic responses of bacteria to osmotic stress. Microbiol Rev. 53: 121-147. PMid:2651863 PMCid:PMC372720

Feng G, Tsui HT, Winkler ME. 1996. Depletion of the cellular amounts of the MutS and MutH methyl-directed mismatch repair proteins in stationary-phase Escherichia coli K-12 cells. J Bacteriol. 178: 2388-2396. https://doi. org/10.1128/jb.178.8.2388-2396.1996 PMid:8636043 PMCid:PMC177950

Freeman BC, Chen C and Beattie GA. 2010. Identification of the trehalose biosynthetic loci of Pseudomonas syringae and their contribution to fitness in the phyllosphere. Environ Microbiol. 12: 1486-1497. PMid:20192963

Freeman BC, Chen C, Yu X, Nielsen X, Peterson, Beattie GA. 2013. Physiological and transcriptional responses to osmotic stress of two Pseudomonas syringae strains that differ in epiphytic fitness and osmotolerance. $J$ Bacteriol. 195: 4742- 4752. https://doi.org/10.1128/ JB.00787-13 PMid:23955010 PMCid:PMC3807433

Harris RS, Feng G, Ross KJ, Sidhu R, Thulin C, Longerich S, Szitgety SK, Winkler ME, Rosenberg SM. 1997. Mismatch repair protein MutL becomes limiting during stationary-phase mutation. Genes Dev. 11: 2426-2437. https://doi.org/10.1101/gad.11.18.2426 PMid:9308969 PMCid:PMC316514

Janoshi L, Shimizu I, Kaji A. 1994. Ribosome recycling factor (ribosome releasing factor) is essential for bacterial growth. Proc Natl Acad Sci. 91: 4249-4253. https://doi. org/10.1073/pnas.91.10.4249

Jensen KF, Larsen S. 2003. Dihydroorotate dehydrogenase of Escherichia coli. pp.11-21 In: Selinsky, B.S. (Eds.), Membrane protein protocols; expression, purification and characterization. Humana Press, Towata, NJ. https://doi.org/10.1385/1-59259-400-X:11

Karas VO, Westerlaken I, Meyer AS. 2015. The DNA-binding protein from starved cells (Dps) utilizes dual functions to defend cells against multiple stresses. J Bacteriol. 197: 3206-3215. https://doi.org/10.1128/JB.00475-15 PMid:26216848 PMCid:PMC4560292

Kawasaki S, Satoh T, Todoroki M, Niimura Y. 2009. b-Type dihydroorotate dehydrogenase is purified as a $\mathrm{H} 2 \mathrm{O} 2$-forming NADH oxidase from Bifidobacterium bifidum. Appl Environ Microbiol. 75: 629-636. https://doi.org/10.1128/ AEM.02111-08 PMid:19060157 PMCid:PMC2632149

Kets EPW, Galinski EA, de Wit M, de Bont JAM, Heipieper HJ. 1996. Mannitol, a novel bacterial compatible sol- 
KARKERA ASHWITHA et al.

ute in Pseudomonas putida S12. J Bacteriol. 178: 6665- 6670. https://doi.org/10.1128/jb.178.23.66656670.1996 PMid:8955280 PMCid:PMC178559

Kuhlmann AU, Hoffmann T, Bursy J, Jebbar M, Bremer E. 2011. Ectoine and hydroxyectoine as protectants against osmotic and cold stress: Uptake through the SigB-controlled betaine-choline-carnitine transportertype carrier EctT from Virgibacillus pantothenticus $J$ Bacteriol. 193: 4699-4708. https://doi.org/10.1128/ JB.05270-11 PMid:21764932 PMCid:PMC3165649

Kusuya Y, Kurokawa K, Ishikawa S, Ogasawara N, Oshima T. 2011. Transcription factor GreA contributes to resolving promoter-proximal pausing of RNA polymerase in Bacillus subtilis cells J Bacteriol. 193: 3090-3099. https://doi.org/10.1128/JB.00086-11 PMid:21515770 PMCid:PMC3133182

Larsen NA, Nash TJ, Morningstar M, Shapiro AB, Joubran C, Blackett CJ, Patten AD, Boriack- Sjodin A, Doig P. 2012. An aminoquinazoline inhibitor of the essential bacterial cell wall synthetic enzyme GlmU has a unique non-protein-kinase-like binding mode. Biochem J. 446: 405-413. https://doi.org/10.1042/BJ20120596 PMid:22721802

Lau SKP, Fan RYY, Ho TCC, Wong GKM, Tsang AKL, Teng JLL, Chen W, Watt RM, Curreem SOT, Tse H, Yuen K, Woo PCY. 2011. Environmental adaptability and stress tolerance of Laribacter hongkongensis: a genome-wide analysis. Cell Biosci. 1: 22-49. https://doi.org/10.1186/2045-37011-22 PMid:21711489 PMCid:PMC3135505

Lenhart JS, Brandes ER, Schroeder JW, Sorenson RJ, Showalter HD, Simmons LA. 2014. RecO and RecR are necessary for RecA loading in response to DNA damage and replication fork stress. J Bacteriol. 196: 2851-2860. https://doi.org/10.1128/JB.01494-14 PMid:24891441 PMCid:PMC4135682

Li K, Jiang T, Yu B, Wang L, Gao C, Ma C, Xu P, Ma Y. 2012. Transcription elongation factor GreA has functional chaperone activity. PLoS One 7: 47521-47527. https:// doi.org/10.1371/journal.pone.0047521 PMid:23251328 PMCid:PMC3521015

Liang X, Zhang L, Natarajan SK, Becker DF. 2013. Proline mechanisms of stress survival. Antioxid Redox Signal. 19: 998-1011. https://doi.org/10.1089/ars.2012.5074 PMid:23581681 PMCid:PMC3763223

Lindgren JK, Thomas VC, Olson ME, Chaudhari SS, Nuxoll AS, Schaeffer CR, Lindgren KE, Jones J, Zimmerman MC, Dunman PM, Bayles KW, Fey PD. 2014. Arginine deaminase in Staphylococcus epidermidis functions to augment biofilm maturation through $\mathrm{pH}$ homeostasis. J Bacteriol. 196: 2277-2289. https://doi.org/10.1128/ JB.00051-14 PMid:24727224 PMCid:PMC4054176

Liu X, BasuU, MillerP,McMullenL. 2014. Stress and adaptation of Listeria monocytogenes 08-5923 exposed to a sublethal dose of carnocyclin A. Appl Environ Microbiol. 80: 3835-3841. https://doi.org/10.1128/AEM.00350-14\%20 PMid:24747893\%20 PMCid:PMC4054213

Louis P, Galinski EA. 1997. Characterization of genes for the biosynthesis of the compatible solute ectoine from Marinococcus halophilus and osmoregulated expression in Escherichia coli. Microbiol. 143: 1141-1149. https:// doi.org/10.1099/00221287-143-4-1141 PMid:9141677

Lovett ST. 2011. The DNA exonucleases of Escherichia coli. EcoSal. Plus. doi:10.1128/ecosalplus.4.4.7. https://doi. org/10.1128/ecosalplus.4.4.7

Lusetti SL, Cox MM. 2002. The bacterial RecA protein and the recombinational DNA repair of stalled replication forks. Ann Rev Biochem. 71: 71-100. https:// doi.org/10.1146/annurev.biochem.71.083101.133940 PMid:12045091

Macomber L, Elsey SP, Hausinger RP. 2011. Fructose1,6-bisphosphate aldolase (class II) is the primary site of nickel toxicity in Escherichiacoli.MolMicrobiol.82:12911300. https://doi.org/10.1111/j.1365-2958.2011.07891.x PMid:22014167 PMCid:PMC3225726

Maguire M, Coates ARM, Henderson B. 2002. Chaperonin 60 unfolds its secrets of cellular communication. Cell Stress Chaperones 7: 317-329. https://doi.org/10.1379/14661268\%282002\%29007\%3C0317:CUISOC\%3E2.0.CO $\% 3 \mathrm{~B} 2$

Mande SC, Kumar SCM. 2013. Evolution of bacterial chaperonin 60 paralogues and moonlighting activity. pp. 101-121. In: Henderson, B. (Ed.), Moonlighting cell stress proteins in microbial infections, heat shock proteins. Springer Science, Dordrecht. https://doi. org/10.1007/978-94-007-6787-4_7

Marquis RE, Bender GR, Murray DR, Wong A. 1987. Arginine deiminase system and bacterial adaptation to acid environments. Appl Environ Microbiol. 53: 198-200. PMid:3103530 PMCid:PMC203628

Meena KK, Sorty AM, Bitla UM, Choudhary K, Gupta P, Pareek A, Singh DP, Prabha R, Sahu PK, Gupta VK, Singh HB, Krishanani KK, Minhas PS. 2017. Abitoic stress reponses and Microbe- mediated mitigation in plants: The omics strategies. Fron Plant 
Molecular mechanisms adopted by abiotic stress tolerant Pseudomonas fluorescens (NBAII-PFDWD) in response to in vitro osmotic stress

Sci. 8:172. https://doi.org/10.3389/fpls.2017.00172

PMid:28232845 PMCid:PMC5299014

Mochalkin I,Lightle S, Zhu S, Ohren JF, SpessardC, ChirgadzeNY, Banotai C, Melnick M, McDowell L. 2007. Characterization of substrate binding and catalysis in the potential antibacterial target $\mathrm{N}$-acetylglucosamine-1-phosphate uridyltransferase (GlmU). Prot Sci. 16: 2657-2666. https://doi.org/10.1110/ ps.073135107 PMCid:PMC2222810

Msadek T, Dartois V, Kunst F, Herbaud ML, Denizot F, Rapoport G. 1998. ClpP of Bacillus subtilis is required for competence development, motility, degradative enzyme synthesis, growth at high temperature and sporulation. Mol Microbiol. 27: 899-914. https://doi. org/10.1046/j.1365-2958.1998.00735.x PMid:9535081

Nurenberg E, Tampe R. 2013. Tying up loose ends: ribosome recycling in eukaryotes and archaea. Trends Biochem Sci. 38: 64-74. https://doi.org/10.1016/j.tibs.2012.11.003 PMid:23266104

Oliver A, Baquero F, Blazquez J. 2002. The mismatch repair system (mutS, mutL and uvrD bgenes) in Pseudomonas aeruginosa: molecular characterization of naturally occurring mutants. Mol Microbiol. 43:1641-1650. https://doi.org/10.1046/j.1365-2958.2002.02855.x PMid:11952911

Pastor M, Salvador M, Argando-a M, Bernal V, Reina-Bueno M, Csonka LN, Iborra LJ, Vargas C, Nieto NJ, Cánovas M. 2010. Ectoines in cell stress protection: Uses and biotechnological production. Biotech Adv. 28: 782801. https://doi.org/10.1016/j.biotechadv.2010.06.005 PMid:20600783

Paul D, Dineshkumar N, Nair S. 2006. Proteomics of a plant growth promoting rhizobacterium, Pseudomonas fluorescnes MSP-393, subjected to salt shock. World $J$ Microbiol Biotechnol. 22: 369-374. https://doi. org/10.1007/s11274-005-9043-y

Perez-Arellano I, Carmona-Alvarez F, Martınez AI, Rodriguez-Diaz J, Cervera J. 2010. Pyrroline-5carboxylate synthase and proline biosynthesis: From osmotolerance to rare metabolic disease. Prot Sci. 1: 372-382. https://doi.org/10.1002/pro.340

Rangeshwaran R, Ashwitha K, Sivakumar G, Jalali SK. 2013. Analysis of proteins expressed by an abiotic stress tolerant Pseudomonas putida (NBAII-RPF9) isolate under saline and high temperature conditions. Curr Microbiol. 67: 659-667. https://doi.org/10.1007/s00284-0130416-4 PMid:23828182
Ryzhikov M, Koroleva O, Postnov D, Tran A, Korolev S. 2011. Mechanism of RecO recruitment to DNA by singlestranded DNA binding protein. NucleicAcids Res. 1: 1-10. https://doi.org/10.1093/nar/gkr199

Sandhya V, Ali SkZ, Grover M, Reddy G, Venkateswarlu B. 2009. Alleviation of drought stress effects in sunflower seedlings by exopolysaccharides producing Pseudomonas putida strain P45. Biol Fert Soil. 46: 17-26. https://doi.org/10.1007/s00374-009-0401-z

Schelin J, Lindmark F, Clarke A.K. 2002. The clpP multigene family for the ATP-dependent Clp protease in the cyanobacterium Synechococcus. Microbiol. 148: 2255-2265. https://doi.org/10.1099/00221287-148-7-2255\%20 PMid:12101312

Song L, Wang G, Malhotra A, Deutscher MP, Liang W. 2016. Reversible acetylation on Lys501 regulates the activity of RNase II. Nucleic Acids Res. 44: 1979-1988. https://doi.org/10.1093/nar/gkw053 PMid:26847092 PMCid:PMC4797298

Starosta AL, Lassak E, Jung K, Wilson DN. 2014. The bacterial translation stress response. FEMS Microbiol Rev. 38: 172-1201. https://doi.org/10.1111/1574-6976.12083 PMid:25135187 PMCid:PMC4227928

Takahagi M, Iwasaki H, Nakata A, Shinagawa H. 1991. Molecular analysis of the Escherichia coli ruvC gene, which encodes a Holliday junction-specific endonuclease. J Bacteriol. 173: 5747-5753. https:// doi.org/10.1128/jb.173.18.5747-5753.1991\%20 PMid:1885548 PMCid:PMC208306

Torrents E, Grinberg I, Gorovitz B, Lundstrom H, Borovok I, Aharonowitz Y, Sjoberg B, Cohen, G. 2007. NrdR controls differential expression of the Escherichia coli ribonucleotide reductase genes. $J$ Bacteriol. 189: 50125021. https: // doi. org/ 10.1128/JB.00440-07 PMid : 17496099 PMCid : PMC1951866

Udaondo Z, Duque E, Fernandez M, Molina L, Torre J, Bernal P, Niqui J, Pini C, Roca A, Matilla MA, MolinaHenares MA, Silva-Jimenez H, Navarro-Aviles G, Busch A, Lacal J, Krell T, Segura A and Ramos J. 2012. Analysis of solvent tolerance in Pseudomonas putida DOT-T1E based on its genome sequence and a collection of mutants. FEBS Lett. 586: 2932-2938. https://doi. org/10.1016/j.febslet.2012.07.031 PMid:22819823

Villarroya M, Perez-Roger I, Macia F, Armengod ME. 1998. Stationary phase induction of dnaN and recF, two genes of Escherichia coli involved in DNA replication and 
KARKERA ASHWITHA et al.

repair. EMBOJ. 17: 1829-1837. https://doi.org/10.1093/ emboj/17.6.1829 PMid:9501104 PMCid:PMC1170530

Wood JM. 1999. Osmosensing by bacteria: Signals and membrane-based sensors. Microbiol Mol Biol Rev. 63: 230-262. PMid:10066837 PMCid:PMC98963

Wood JM. 2015. Bacterial responses to osmotic challenges. J Gen Physiol. 145: 381-388. https://doi.
org/10.1085/jgp.201411296\%20PMid:25870209\%20 PMCid:PMC4411257

Zhang YM, Rock CO. 2008. Acyltransferases in bacterial glycerophospholipid synthesis. J Lipid Res. 49: 1867-1874. https://doi.org/10.1194/jlr.R800005-JLR200 PMid:18369234 PMCid:PMC2515527 